\title{
Freezing-Thawing and Wetting-Drying Behavior of Clayey Soil Stabilized with Lime and Silica Fume
}

\author{
Fatih YILMAZ ${ }^{1 *} \mathbb{D}$, Ersin DEMIR ${ }^{2} \mathbb{D}$ \\ ${ }^{1}$ Bayburt University Civil Engineering Department, Bayburt, Turkey \\ ${ }^{2}$ Bayburt University Civil Engineering Department, Bayburt, Turkey
}

Geliş / Received: 2.12.2019, Kabul / Accepted: 19.12.2019

\begin{abstract}
Soil stabilization is defined as improving the physical, chemical, hydraulic and mechanical properties of soils that are insufficient in terms of engineering properties. In this study, stabilization of high plasticity clayey soil with silica fume and lime was investigated to examine strength and durability behavior of stabilized soil. The test samples were prepared by adding 5\%,10\%, 15\% and 20\% of silica fume, without lime and with 6\% lime to the natural soil which is a high plasticity clay $(\mathrm{CH})$ according to the Unified Soil Classification System. The curing time is 7 and 28 days. At the end of these curing periods, unconfined compressive strength tests were performed. After 28 days of curing, 12 wetting-drying and freezing-thawing cycles were completed and durability behavior of the samples were examined. In the light of the obtained data, it was determined that SLS samples containing silica fume and lime had higher strength values than SL samples containing only lime. Silica fume increase the strength values after curing periods and has positive effects on the soil durability in terms of freezing-thawing test.
\end{abstract}

Keywords: Soil stabilization, lime, silica fume, freezing-thawing, wetting-drying

Kireç ve Silis Dumanı ile Stabilize Edilen Killi Zeminin Donma-Çözülme ve Islanma Kuruma Davranışı Öz

Zemin stabilizasyonu, mühendislik özellikleri açısından yetersiz olan zeminlerin fiziksel, kimyasal, hidrolik ve mekanik özelliklerinin iyileştirilmesi olarak tanımlanmaktadır. Bu çalışmada, silis dumanı ve kireçle stabilize edilmiş yüksek plastisiteli killi bir zeminin dayanım ve durabilite davranışı incelenmiştir. Test numuneleri, Birleştirilmiş Zemin Sınıflandırma Sistemi'ne göre yüksek plastisiteli bir kil (CH) olan doğal zemine kireçsiz ve $\% 6$ kireçli olarak \% 5,\% 10,\% 15 ve\% 20 silis dumanı eklenerek hazırlanmıştır. Hazırlanan numunelerin kür süresi 7 ve 28 gündür. Bu kür sürelerinin sonunda, serbest basınç dayanımı testi yapılmıştır. 28 günlük kür süresinin ardından 12 ıslanma-kuruma ve donma-çözülme döngüsü tamamlanmış ve numunelerin davranışları incelenmiştir. Elde edilen veriler 1şığında, silis dumanı ve kireç içeren SLS örneklerinin sadece kireç içeren SL örneklerinden daha yüksek dayanım değerlerine sahip olduğu tespit edilmiştir. Silis dumanı, kür sürelerinin ardından dayanım değerlerini arttırmıştır ve donma-çözülme testi açısından zemin durabilitesi üzerinde olumlu etkilere sahiptir.

Anahtar Kelimeler: Zemin stabilizasyonu, kireç, silis dumanı, donma-çözülme, ıslanma-kuruma 


\section{Introduction}

Soil mechanics is the discipline of science which examines the behavior and properties of soils. The main purpose of soil improvement methods is to improve the properties of soils which are weak in terms of engineering properties such as strength, durability and permeability. The methods to be used to solve the problems of the soils which are insufficient in terms of engineering properties are as follows;

-Scraphing the unwanted soil and replacing it with a suitable soil,

-Increasing the quality of the material used in the superstructure project and changing the dimensions of the structural elements,

-Stabilization engineering properties of the soil (Balta, 1984).

Chemical stabilization occurs as a result of chemical reactions when different additives are mixed into the soil. The properties of the soil are improved with chemical stabilization (Aytekin, 2004). Chemical stabilization method is the most economical and most appropriate method applied in soil stabilization (Kukko, 2000).

Lime is the preferred material for chemical stabilization due to its high amount in nature and low cost (Y1lmaz, 2015). Lime stabilization is widely and effectively used in clayey soils (Ladd et al. 1960). Lime is white and hardens in water or air. When mixed with water, it is an inorganic based binder (Ghabaee, 2015).

It is determined that the presence of more than $10 \%$ lime in clayey soils is not effective in increasing the strength (Ola, 1978). Another experiment by adding certain amounts of lime to clayey soils done by Bell (1996) showed that the optimum percentage of lime is $4-6 \%$. In the study conducted by Eren and Filiz (2009), it was determined that the swelling behavior of the soil was terminated with the use of lime as an additive at the rate of $8 \%$.

Pozzolans take their name from the town of Pozzuoli in Italy. They are materials containing a large amount of colloidal elements and silica in their structure. In Turkey, there are many natural pozzolan sources in the Black Sea, Central Anatolia, Mediterranean, Marmara and Aegean regions (Okuyucu, 1998). Pozzolans gain binding properties when combined with another binder, lime or cement. Pozzolans are generally combine with lime and show binding properties (Y1lmaz, 2015). Evaluation of pozzolans in soil stabilization studies is widely used (Yilmaz et al., 2015; Calik and Sadoglu, 2014a and b; Celik and Nalbantoglu, 2013; Yilmaz and Fidan, 2017; Yilmaz and Yurdakul, 2017; Yilmaz and Fidan, 2018).

Silica fume is an industrial by-product with pozzolanic properties, which is caused by the reduction of silicon metal alloys or silicon metal to quartz with a high purity of $2000{ }^{\circ} \mathrm{C}$ temperature. Very high amount of $\mathrm{SiO}$ gas occur during this process. $\mathrm{SiO}$ gas passes into amorphous $\mathrm{SiO}_{2}$ state by contacting with cold air and condensing. This exposed material is called "microsilika" or "silica fume" (Demir, 2019). Silica fume, because it is a very finegrained and amorphous material, it has a great pozzolanic property due to its high content of $\mathrm{SiO}_{2}$ (Erdoğan, 2003). Silica fume is usually gray. As the carbon content increases, the color darkens. Even when mixed with water, its color turns black (Malhatra, 1997). 
The aim of this study is stabilization of high plasticity clayey soil with silica fume and lime in different ratios and curing periods.

\section{Material and Methods}

The materials used in this study are natural soil, lime and silica fume. Samples were prepared by adding silica fume in $5 \%, 10 \%$, $15 \%$ and $20 \%$ ratios with/without $6 \%$ of lime to the soil. Sieve analysis was conducted to determine soil class. In accordance with the Unified Soil Classification System, the soil class is specified as high plasticity clay $(\mathrm{CH})$. The notation of test samples is given in Table 1.

Table 1. Notations

\begin{tabular}{|l|l|}
\hline Mixing ratios of test samples & Notation \\
\hline Natural soil & $\mathrm{S}$ \\
\hline Natural soil and 5\% silica fume & $\mathrm{SS} / 5$ \\
\hline Natural soil and 10\% silica fume & $\mathrm{SS} / 10$ \\
\hline Natural soil and 15\% silica fume & $\mathrm{SS} / 15$ \\
\hline Natural soil and 20\% silica fume & $\mathrm{SS} / 20$ \\
\hline Natural soil and 6\% lime & $\mathrm{SL}$ \\
\hline $\begin{array}{l}\text { Natural soil, 6\% lime and 5\% } \\
\text { silica fume }\end{array}$ & $\mathrm{SLS} / 5$ \\
\hline $\begin{array}{l}\text { Natural soil, 6\% lime and 10\% } \\
\text { silica fume }\end{array}$ & SLS/10 \\
\hline $\begin{array}{l}\text { Natural soil, 6\% lime and 15\% } \\
\text { silica fume }\end{array}$ & SLS/15 \\
\hline $\begin{array}{l}\text { Natural soil, 6\% lime and 20\% } \\
\text { silica fume }\end{array}$ & SLS/20 \\
\hline
\end{tabular}

The different behavior of the soil depending on the water content has been expressed experimentally by Atterberg. Atterberg limits are mainly liquid limit and plastic limit. In the scope of this study, cone penetrometer method was used for liquid limit test.

Compaction is a mechanical process that makes the soil tighter if the soil is laid down in layers. The purpose of the compaction is to obtain the maximum density in the minimum air space. In this study, the optimum water content value corresponding to the maximum dry density value of the sample was determined by applying standard compaction test. Previously dried amount of soil is used for this test. A certain amount of water is added to this soil and mixed well. The prepared sample is compressed into a cylindrical steel mold by hitting 25 mallet strokes on each layer in the form of three stages. The compressed soil is then removed from the mold without losing its volumetric stability. After the extracted sample is divided into 3 equal parts, water content test is performed on one part. This process is repeated at least five times by adding water to the sample. The data obtained from the experiment are indicated on the graph $\rho_{k}-\mathrm{W}$ and the compaction graph is drawn. From the peak of this graph, $\mathrm{w}_{\mathrm{opt}}$ and $\rho_{\mathrm{kmax}}$ are found.

After compaction test, the unconfined compressive strength test was performed. This test is mostly used to determine the strength of clayey soils. Within the scope of this study, cylindrical samples of $50 \mathrm{~mm}$ diameter and $100 \mathrm{~mm}$ height were prepared. The prepared samples were cured in desiccator for 7 and 28 days and then subjected to unconfined compressive strength test. Samples were subjected to 12 wetting-drying and freezingthawing cycles at the end of 28 days of curing period. Freezing-thawing and wetting drying tests were performed according to ASTM D 560 (1996) and ASTM D 559 (1996), respectively. For wetting-drying cycle tests, the weight of the test specimens in the dry 
state at the end of curing was weighed. Then, the samples were left into the water filled tank prepared for this test. The next day the samples were taken from inside the water and left to dry in a dry place and 24 hours later, the samples which were left to dry were weighed. This process was completed in the form of 12 wetting-drying cycles. At the end of the test, it was determined whether the samples were able to maintain their volumetric stability or not by examining the mass losses in the samples. For freezing-thawing tests, after 28 days of curing and 12 freezing-thawing cycle at $-20{ }^{\circ} \mathrm{C}$ and $24{ }^{\circ} \mathrm{C}$ temperature, the unconfined compressive strength test was performed.

Cylindrical samples with a diameter of $50 \mathrm{~mm}$ and height of $100 \mathrm{~mm}$ were prepared for freeze-thaw test. These samples were cured in a desiccator for 28 days and placed in a freezethaw cabinet and subjected to 12 freeze-thaw cycles. There were 12 cycles to be 1 day at 20 and $24{ }^{\circ} \mathrm{C}$ in the freeze-thaw cabinet. After the completion of this cycle, the samples were subjected to unconfined compressive strength test and their strength was determined. Thus, the strength losses after freezing-thawing cycle were determined.

\section{Results}

The liquid limit, plastic limit and plasticity index values of the samples obtained by taking ASTM D 4318 (2010) into consideration are shown in Table 2. When the consistency limits are examined, it was seen that the liquid limit value of the high plasticity soil sample is the highest and the plastic limit value is lower than the other specimens. While the liquid limit value of SL specimen decreased compared to the natural soil sample, an increase in the plastic limit value was determined. The lowest liquid limit value among these specimens was found in SLS samples. As the silica content increases, liquid limit values decrease in these specimens.

Table 2. Atterberg limits

\begin{tabular}{|l|c|c|c|}
\hline Specimen & $\begin{array}{l}\text { Liquid } \\
\text { limit (\%) }\end{array}$ & $\begin{array}{l}\text { Plastic } \\
\text { limit (\%) }\end{array}$ & $\begin{array}{l}\text { Plasticity } \\
\text { index (\%) }\end{array}$ \\
\hline S & 60,8 & 30 & 30,8 \\
\hline SS/5 & 57,1 & 32,7 & 24,4 \\
\hline SS/10 & 56,7 & 33,3 & 23,4 \\
\hline SS/15 & 56,6 & 33,9 & 22,7 \\
\hline SS/20 & 56,2 & 32,3 & 23,9 \\
\hline SL & 54,9 & 34,5 & 20,4 \\
\hline SLS/5 & 50,8 & 36,2 & 14,6 \\
\hline SLS/10 & 50,6 & 36,2 & 14,4 \\
\hline SLS/15 & 50,5 & 36,3 & 14,2 \\
\hline SLS/20 & 50,4 & 35,1 & 15,3 \\
\hline
\end{tabular}

Maximum dry density and optimum water content values of test specimens were performed according to ASTM D 698 (2007). Table 3 shows the maximum dry density and optimum water content of test specimens. When the compaction results of SLS mixtures were examined, it was found that there were generally increases in optimum water content values and decreases in maximum dry density values. While the maximum dry density values of SS specimens decreased compared to natural soil, optimum water contents values increased up to $15 \%$. Optimum water content of SL and SLS samples ranged from $25 \%$ to $26 \%$, while S and SS samples ranged from $21 \%$ to $25.5 \%$. The highest maximum dry density was found in the natural soil sample. 
Table 3. Compaction test results

\begin{tabular}{|l|c|c|}
\hline Specimen & $\begin{array}{l}\text { Maximum dry } \\
\text { density, Mg/m }\end{array}$ & $\begin{array}{l}\text { Optimum water } \\
\text { content, } \%\end{array}$ \\
\hline S & 1,63 & 22,5 \\
\hline SS/5 & 1,58 & 24,0 \\
\hline SS/10 & 1,59 & 25,5 \\
\hline SS/15 & 1,54 & 22,5 \\
\hline SS/20 & 1,56 & 21,0 \\
\hline SL & 1,50 & 26,0 \\
\hline SLS/5 & 1,56 & 25,0 \\
\hline SLS/10 & 1,51 & 25,5 \\
\hline SLS/15 & 1,49 & 26,0 \\
\hline SLS/20 & 1,47 & 26,0 \\
\hline
\end{tabular}

Unconfined compressive strength tests were carried out in accordance with ASTM D 2166 (2006). Table 4 shows strength test results of the specimens after 7 and 28 days of curing. As it can be seen from Table 4, it was found that the addition of lime to the natural soil at an optimum ratio increased the strength values approximately 5 times. Unconfined compressive strength of natural soil did not change much after different curing times. For specimens containing only silica fume, the maximum strength was obtained from SS/15 specimen. This strength value is more than twice the value of natural soil strength. The use of silica fume with lime produced very impressive strength results. The maximum strength of specimens containing lime and silica fume was obtained from SLS/15 specimen. Figure 1 illustrates the strength test results of specimens after 7 and 28 days of curing period.
Table 4. Unconfined compressive strength test results

\begin{tabular}{|l|c|c|}
\hline \multirow{2}{*}{ Specimen } & \multicolumn{2}{|c|}{ Strength $(\mathrm{kPa})$} \\
\cline { 2 - 3 } & 7 days & 28 days \\
\cline { 2 - 3 } S & 115,2 & 120,3 \\
\hline SS/5 & 118,3 & 127,0 \\
\hline SS/10 & 124,7 & 192,2 \\
\hline SS/15 & 167,5 & 267,5 \\
\hline SS/20 & 159,5 & 221,5 \\
\hline SL & 560,2 & 657,0 \\
\hline SLS/5 & 692,2 & 761,4 \\
\hline SLS/10 & 1077,0 & 1284,3 \\
\hline SLS/15 & 1152,3 & 1689,5 \\
\hline SLS/20 & 1134,3 & 1417,6 \\
\hline
\end{tabular}

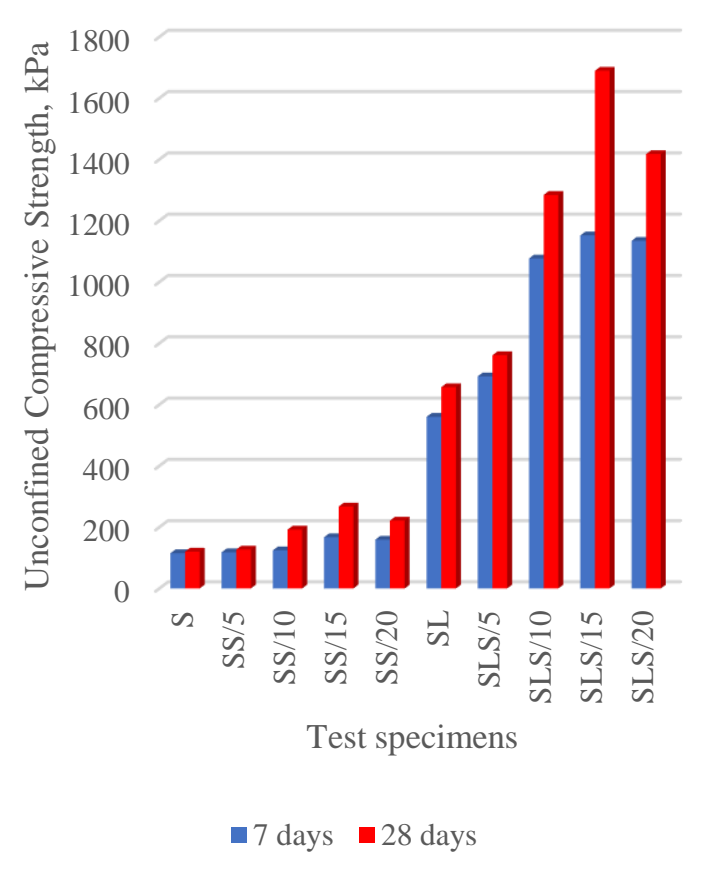

Figure 1. Strength test results 


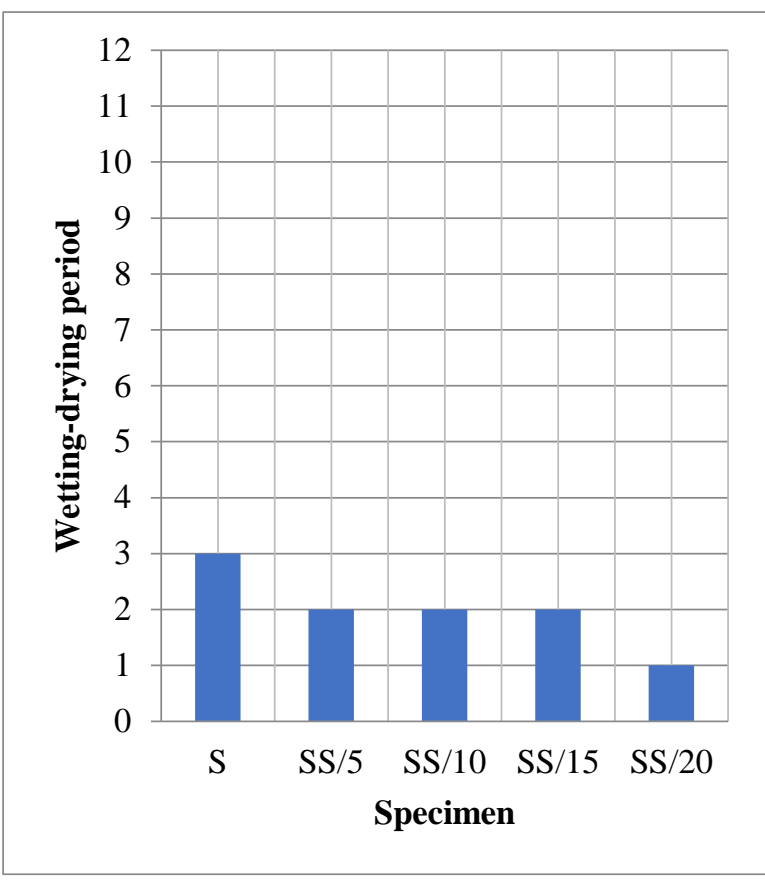

Figure 2. Wetting and drying results of $S$ and SS samples

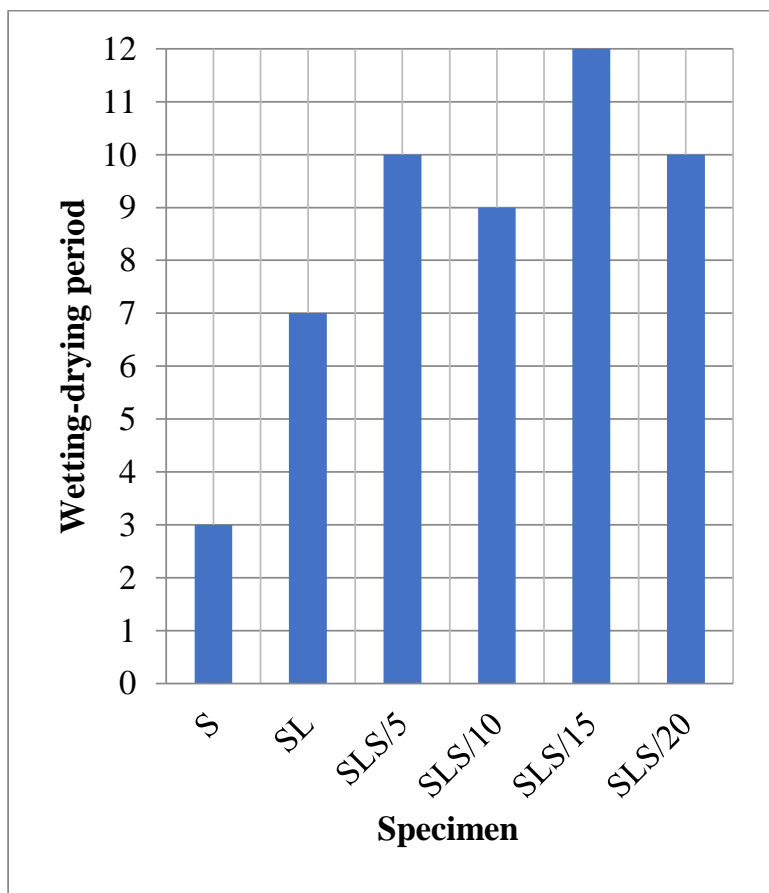

Figure 3. Wetting and drying results of S, SL and SLS samples

Wetting and drying results of test specimens are shown in Figure 2 and Figure 3, respectively. According to the results of the test, it was determined that the natural soil deteriorated its volumetric integrity after 3 days. Specimens containing only silica fume completely lost their volumetric integrity at the end second wetting-drying cycle. The SL specimen lost its volumetric stability after 7 days. SLS/15 was resistant to 12 days wettingdrying period. The use of lime in soil stabilization studies with silica fume has an amendment effect in terms of wetting-drying tests.

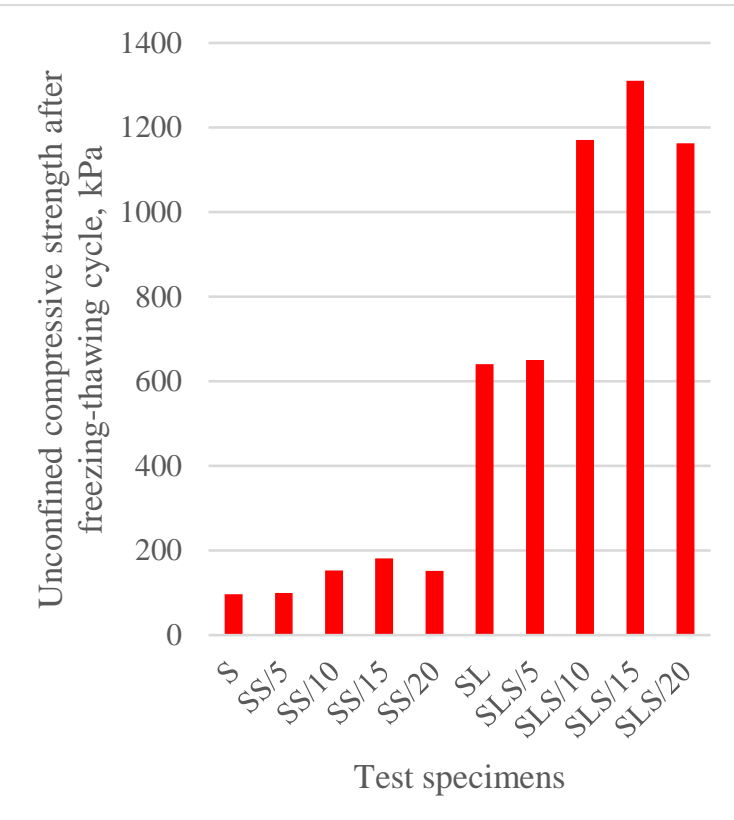

Figure 4. Freezing-thawing test results

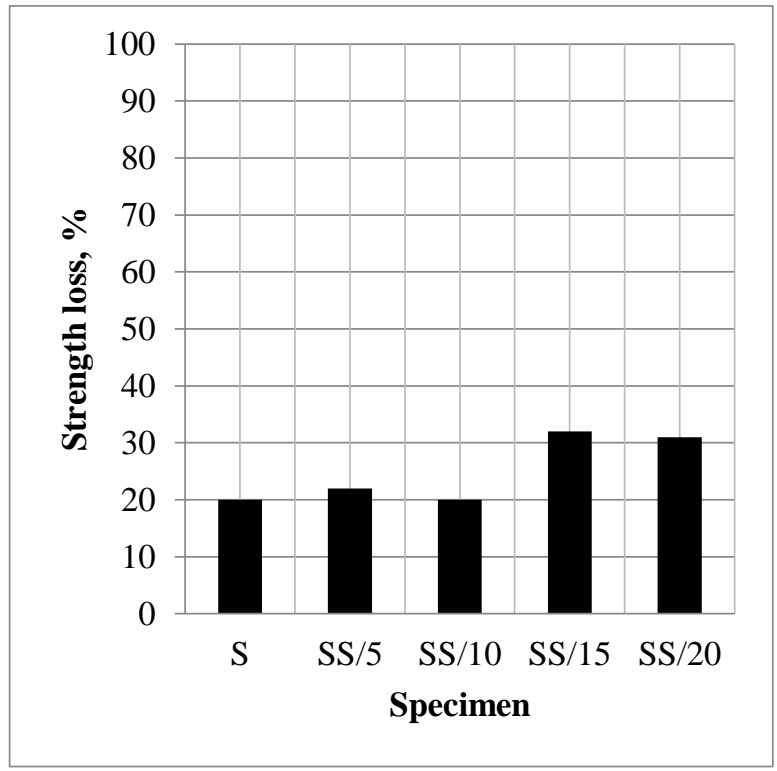

Figure 5. Strength loss of SS specimens after freezing-thawing cycle 


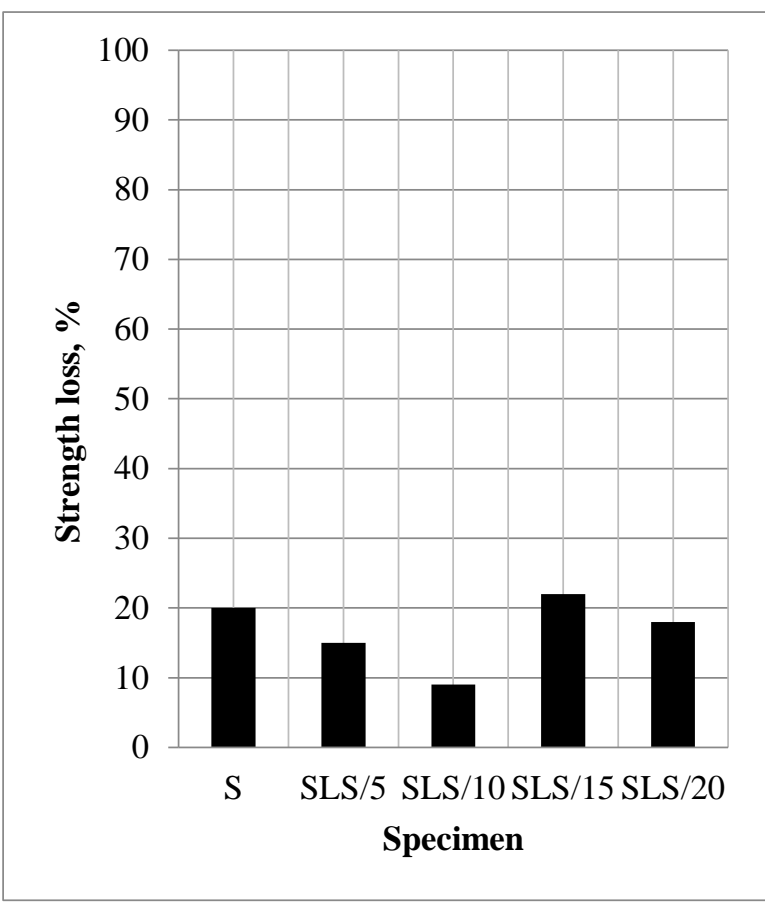

Figure 6. Strength loss of SLS specimens after freezing-thawing cycle
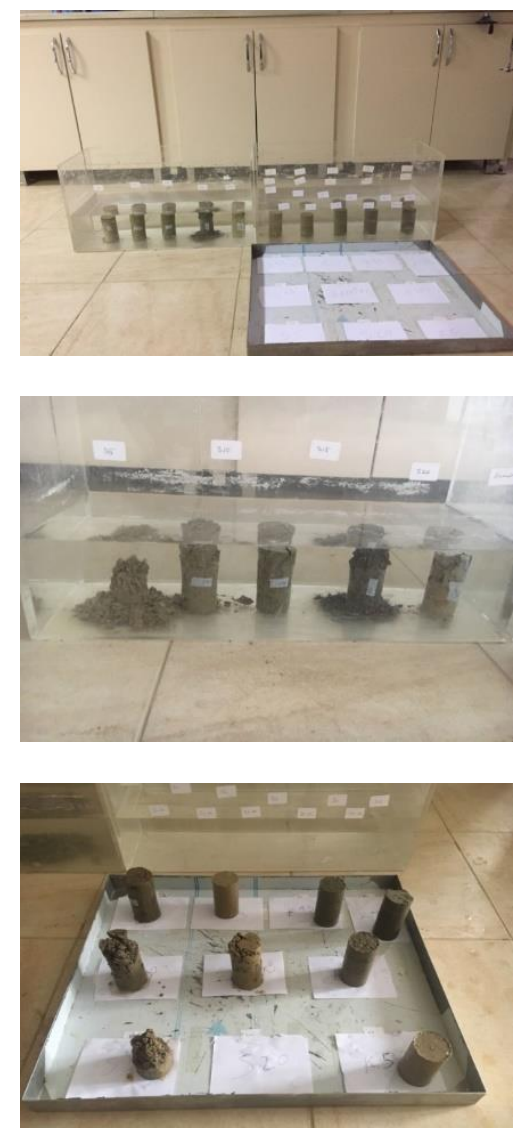

Figure 7. Illustration of wetting-drying cycle
Freezing-thawing test results and strength loss of SS and SLS specimens after freezingthawing cycle were illustrated in Figure 4, Figure 5 and Figure 6, respectively. Illustration of wetting-drying cycle was shown in Figure 7. When unconfined compressive strength test values after freezing-thawing were examined, it was observed that there was a decrease in strength values of SS mixtures. In SLS mixtures, it was observed that strength values were higher compared to SL mixtures. The loss of strength of the SLS/10 specimen is less than $10 \%$. Up to $30 \%$ strength losses occurred in specimens containing only silica fume. Accordingly, it can be said that the use of lime and silica fume together will be more beneficial in terms of freezing-thawing effects.

\section{Conclusions}

The following findings were obtained after this experimental study.

- $\quad$ Stabilization the clayey soil only with silica fume reduced the liquid limit values. A similar behavior was observed in terms of liquid limit values in the addition of lime to natural soil. Adding silica fume to SL mixtures did not cause significant changes in liquid limit values.

- It was seen that usage of only silica fume was not effective for wetting-drying cycles, the samples were lost their volumetric stability. The use of lime and silica fume together is quite crucial in terms of wettingdrying experiments.

- $\quad$ Freeze-thaw tests indicated that strength losses of SLS samples were found to be less than SS samples. This result showed that it is more appropriate to use lime and silica fume together in soil stabilization.

- $\quad$ As a result of this experimental study, it was concluded that the silica fume, which is 
an additive, has a positive effect on the strength behavior of clayey soil. In terms of strength and durability, usage of silica fume and lime together in soil stabilization is more effective than the use of silica fume or lime alone.

\section{References}

Aytekin, M. (2004). "Deneysel Zemin Mekaniği”, Teknik Yayınevi, Ankara.

Balta, İ. 1984. "Doğu Karadeniz Bölgesi topraklarının çimento ve kireçle stabilizasyonu", $\mathrm{PhD}$. Thesis, Karadeniz Technical University, Graduate Institute of Natural and Applied Sciences, Trabzon.

Bell, F. G. 1996. "Lime stabilization of clay minerals and soils", Engineering Geology, 42 (4), 223-237.

Calik, U. and Sadoglu, E. 2014a. "Classification, shear strength, and durability of expansive clayey soil stabilized with lime and perlite", Natural Hazards, 71 (3), 12891303.

Calik, U. and Sadoglu, E. 2014b. "Engineering properties of expansive clayey soil stabilized with lime and perlite", Geomechanics and Engineering, 6 (4), 403418.

Celik, E. and Nalbantoglu, Z. 2013. "Effects of ground granulated blastfurnace slag (GGBS) on the swelling properties of limestabilized sulfate-bearing soils", Engineering Geology, 163, 20-25.

Demir, E. 2019. "Yüksek plastisiteli kil stabilizasyonunda silis dumanı ve mermer atıklarının kireçle beraber kullanılabilirliğinin araştırılması", M. Sc. Thesis, Bayburt University, Graduate Education Institute, Bayburt.

Erdoğan, T. Y. (2003). "Admixtures for Concrete", Middle East Technical University Press, Ankara.

Eren, S. and Filiz, M. 2009. "Comparing the conventional soil stabilization methods to the consolid system used as an alternative admixture matter in Isparta Darıdere material", Construction and Building Materials, 23, 2473-2480.

Ghabaee, S. 2015. "Kireç ile Stablize Edilmiş Bentonitin Kür Süresinin Mukavemet Üzerindeki Etkisi" M. Sc. Thesis, İstanbul Technical University, Institute of Science and Technology, İstanbul.

Kukko, H. 2000. "Stabilization of clay with inorganic by-products", Journal of Materials in Civil Engineering, 12 (4), 307-309.

Ladd, C.C., Moh, Z.C. and Lambe, T.W. 1960. "Recent Soil-Lime Research at the Massachusetts I.T.", Hihgway Research Board, 262, pp. 64-85.

Malhatra, V. M. (1997). "Mineral admixtures. concrete construction engineering handbook" Nawy Edward G.CRC Press, New York.

Okucu, A. 1998. "Bigadiç ve Turnatepe (Balıkesir) Yörelerindeki Zeolitik ve Perlitik Tüflerin Puzolanik Özellikleri”, PhD. Thesis, Balıkesir University, Institute of Science, Balıkesir.

Ola, S. A. 1978. "The geology and geotechnical properties of the black cotton soils of Northeastern Nigeria", Engineering Geology, 12, 375-391.

Y1lmaz, F. 2015. "Tüfit taşların zemin stabilizasyonunda kireçle birlikte kullanılabilirliğin standart deneyler ve bilgisayarlı tomografi tekniği ile araştırılması", PhD. Thesis, Karadeniz Technical University, Graduate Institute of Natural and Applied Sciences, Trabzon.

Yilmaz, F. and Fidan, D. 2017. "Effect of wetting-drying cycles on volumetric stability of clayey soil stabilized with lime and perlite", European Journal of Technique, 7 (2), 207218.

Yilmaz, F. and Fidan, D. 2018. "Influence of freeze-thaw on strength of clayey soil stabilized with lime and perlite", Geomechanics and Engineering, 14 (3), 301306. 
Yilmaz, F. and Yurdakul M. 2017. "Evaluating of marble dust for soil stabilization", Acta Physica Polonica A, 132, 710-711.

Yilmaz, F., Kamiloglu, H. A. and Sadoglu, E. 2015. "Soil stabilization with using waste materials against freezing thawing effect", Acta Physica Polonica A, 128, 392-394. 